\title{
SENTIMENT(ALITY) AS A MEANS OF PERSUASION: ON THE THIN ICE OF MANIPULATION IN PROTESTANT SERMONS
}

\author{
Martin Adam
}

\begin{abstract}
Religious discourse represents an area of human communication in which persuasion plays a vital role; religious texts seem to be essentially related to the ultimate objective of religion: to create, mediate and legitimise ideology in order to persuade the reader of the veracity of the religious doctrine (Fairclough 1989, Cotterell \& Turner 1989: 26-33, van Dijk 1998: 317). The paper seeks to investigate the persuasive strategies and linguistic means employed to convey persuasion in English Protestant sermons. The analysis focuses on the rhetorical role of pathos, which is purposefully evoked by the preacher via wilful employment of affect and emotions. Attention will also be paid to the blurred borderline between the intentional use of sentiment and sentimentality, and manipulation.
\end{abstract}

\section{Keywords}

persuasion, sermons, pathos, sentiment, sentimentality, manipulation

\section{Persuasion and persuasive strategies}

Research has convincingly indicated that persuasion represents a genuine component of human interaction, stretching across various genres and discourses, text types and cultures (Fairclough 1989, Dillard \& Pfau 2002, Halmari \& Virtanen 2005, van Dijk 2008, Orts Llopis et al. 2017, Dontcheva-Navratilova et al. 2020). The authors who explore human communication (e.g. Holtgraves 2001, Perloff 2010) see language as a social action and thus conceptualise persuasion as "a symbolic process in which communicators try to convince other people to change their attitudes or behaviours regarding an issue through the transmission of a message in an atmosphere of free choice" (Perloff 2010: 12, cf. van Dijk 2006, 2008, Duffy \& Thorson 2016); they naturally point out the cultural dimension and interactive character of the process, claiming an inherent conative role of language. In the area of rhetoric, scholars (e.g. Connor 2004, Hogan 2013) approach persuasion as part of the more general notion of argumentation which is actually typical of almost all discourses and is used with the ultimate goal of persuading. Finally, linguistic studies on persuasive language examine the linguistic manifestations of persuasive discourse in 
different genres (e.g. Halmari \& Virtanen 2005, Dillard \& Seo 2013). Virtanen and Halmari (2005), for instance, define persuasion as a communicative purpose conveyed by various rhetorical strategies and related "linguistic choices that aim at changing or affecting the behaviour of others or strengthening the existing beliefs and behaviours of those who already agree, the beliefs and the behaviours of persuaders included" (ibid.: 5).

The concept of persuasion, as an eminently context-dependent and audienceoriented phenomenon, has traditionally been approached through the prism of the three classical types of Aristotelian appeal to the audience (summarised e.g. in Halmari \& Virtanen 2005: 5-6, Hogan 2013: 2-5). The rhetorical appeals include: ethos, i.e. the ethical "voice of the persuader, the linguistically mediated message of her or his believability, reliability, and competence" (Halmari \& Virtanen 2005: 5), encompassing, for example, sharing personal experience, claiming common ground, narrative of belonging, building speaker credibility on the basis of authority/expertise; logos, i.e. the appeal to the rationality of the audience, which is achieved, for instance, through causality mechanisms, logical reasoning, reference to facts such as statistical data (Connor 2004, Sperber et al. 2010); and pathos, which represents the emotional appeal and is typically realised by means of expressive evaluation, evoking various emotions, an appeal to fear, hope and the like. It should be noted here that the prominence of the three rhetorical appeals varies across different discourses.

Within the framework of the Aristotelian triad of rhetorical appeals, the concepts of ethos, logos and pathos have perpetually indicated the essence of what came to be labelled much later as persuasive strategies. Individual persuasive strategies are adopted in different individual, professional and linguacultural settings to highlight crucial points, to present ideas as well as to procure one's arguments with the intention of convincing others (Virtanen \& Halmari 2005: 6-7). Such persuasive intent is symptomatic of different spheres of social interaction and appears to foster the underlying motivation of human communication (Dillard \& Pfau 2002, Dillard \& Seo 2013, Halmari \& Virtanen 2005). By their nature, persuasive strategies are classically understood to fall into the broader categories of individual persuasive features manifested through language, such as identity construction, stance and evaluation, dialogicity/ engagement, and various types of intertextuality (van Leeuwen 1996, Virtanen \& Halmari 2005).

In order to achieve the intended persuasive effect in their communication, authors adopt a whole gamut of different techniques, usually mingled in a fusion. Even though persuasion, as a multimodal phenomenon, may be fostered by extra-linguistic means, it is most prominently and successfully manifested 
at the level of language. Persuasion is expressed by virtue of either explicit linguistic realisations (e.g. use of imperatives, reiteration, modality, evaluative vocabulary, choice of personal pronouns, use of questions, etc.), or, alternatively, in a more or less implicit manner (i.e. various rhetorical strategies in which persuasion is more indirect, such as employment of emotions, some interactive features, humour, etc.) (Cotterell \& Turner 1989: 294-299, Dillard \& Pfau 2002, Hogan 2013).

\section{Persuasion in religious discourse}

Besides the discourses of politics, advertising and marketing, which are generally considered persuasive by definition (van Dijk 1998, 2008), in many ways it is religious discourse that adopts persuasion as one of its essential instruments to convince the audience of the truthfulness of the doctrine it presents, be it sermons, theological treatises, doxologies, personal testimonies, evangelistic texts, apologetic argumentation, or the Bible itself (Lempert 2015, Adam 2017, 2019, Dontcheva-Navratilova et al. 2020). Religious discourse pertains to both professional and public/private zones of social interaction, depending on the perspective taken. Whereas the lens of the congregation typically brings about the perceptive, relatively passive side of religion, the prism of the preacher sees religious discourse as an active process and profession (van Dijk 1998, Dontcheva-Navratilova et al. 2020).

The present paper explores the persuasive strategies and linguistic means employed to convey persuasion in English Protestant sermons with special regard to the pathetical appeal. In the corpus-based qualitative analysis, attention will especially be paid to the rhetorical role of pathos, which is purposefully evoked by the preacher via affect and emotions. Research (Dillard \& Seo 2013, cf. Hogan 2013, Lempert 2015, Garzone 2017, Adam 2020: 201-202) has shown that in religious discourse the pathetical appeal is, among other things, effectively reinforced by the intentional juxtaposition of the factual (serious theological content, intertextuality, references to credible sources) on the one hand, and the affective (both positive and negative emotions, sentiment) on the other. It follows that a whole scale of emotions may undoubtedly be evoked in religious discourse; these are, as a rule, meant to boost the persuasive effect, i.e. to promote the doctrine and to make the believers comprehend and accept spiritual truths.

\section{Research corpus and methodology}

The research corpus gathered for the purposes of the present paper (REL-ENG) comprises 50 individual sermons in English that were randomly 
selected from online sources, each of a comparable length. The sermons were delivered by 23 different native speakers of English (anonymised for research purposes). The corpus dataset contains 115,000 words in total and can be found as full-text in Sketch Engine under the heading "REL-ENG new 100,000". All the sermons represent the genre of scripted sermons, which means that these were originally written by the authors to be delivered in a church environment and later published on the website of the church or on the preachers' blogs. Individual examples adduced below are marked with unique codes that consist of the corpus code and the relevant number of the corresponding sermon in the corpus (i.e. REL-ENG-1 to REL-ENG-50).

In order to make the selection representative and, at the same time, thematically comparable, I decided to focus on a single theme only, rather than to deal with a multifaceted complex of sermons; to be more specific, the messages under investigation are all related to Advent and Christmas. Furthermore, to enhance the homogeneity of the corpus, all the sermons are recruited from mainstream Protestant denominations traditionally established in the UK and the USA, viz. Baptist, Presbyterian, Methodist and some other free Protestant denominations. Chronologically speaking, the selected messages are taken evenly from over the last three decades. Thus, the corpus is believed to present a relatively uniform set of reconcilable texts, both in the formal and thematic senses.

As the paper deals with a qualitative analysis of a corpus of scripted sermons, it will largely utilise the analytical framework and methods of discourse and genre analysis (Swales 1990, Bhatia 1993, Hunston 2007). The texts were processed manually for the exploration of rhetorical strategies related to persuasion, particularly pathos.

\section{Sermon as a genre within religious discourse}

Religious discourse in its entirety comprises a multi-layered set of different genres, registers and text types. No matter what the differences are, all items that can be labelled religious are closely related to the basic purpose of religious communication: to create, mediate and reflect ideology in order to persuade the reader of the veracity of the Christian doctrine (Cotterell \& Turner 1989: 26-33, van Dijk 1998: 317). As an effective vehicle of ideology dissemination, persuasion is the flagship of religious texts in both the linguistic and extra-linguistic senses. In this respect analogous to politics, religious discourse aspires to affect society, define standards of people's behaviour and set values; one of the most effective vehicles of conveying ideology in religious discourse is naturally persuasion (Dontcheva-Navratilova et al. 2020: 46). In line with this claim is van Dijk's (1998) argument, "discourse has a special function in the 
expression, implementation and especially the reproduction of ideologies, since it is only through language use, discourse or communication [...] that they can be explicitly formulated" (ibid.: 316-317). In other words, by means of persuasion the two-fold mission of religious discourse is fulfilled: the audience is persuaded of the church's teaching and Christian ideology is legitimised.

As mentioned above, the present research deals with the scripted version of Protestant sermons that originally were either meant to be read out loud at church or were first delivered from the pulpit and then written down for filing or publication purposes. By definition, a sermon is "discourse from a pulpit" (Onions 1996: 812). It is a religious speech which has a distinct rhetorical style and structure and is delivered typically in a church building. Sermons constitute a part of secondary religious discourse, which is represented by writings that comment on, further discuss, disseminate or interpret the primary religious texts (above all the Bible), such as biblical commentaries (i.e. a distinct genre of theological literature interpreting the Scriptures) or homilies delivered in a church.

The communicative intention of sermons resides, above all, in sharing the church doctrine, its explication and application. Technically, sermons embody authentic, live and, to a large extent, monologic communication with a shared deictic centre (Dontcheva-Navratilova et al. 2020: 47-48). The audience of sermons is by nature heterogeneous, since it comprises believers and regular as well as occasional visitors. The inner community dynamic is interactive and involves asymmetrical relations of power deriving from the hierarchical relation between the preacher's authority and the audience's relative submission. The existence of an audience goes logically hand in hand with the possibility of persuasion (Cotterell \& Turner 1989: 27-28, Virtanen \& Halmari 2005: 7, Overstreet 2014).

\section{Relative use of sentiment in persuasion}

In comparison with other persuasive discourses, the religious one is understood to be unique in that it employs all three components of Aristotelian appeal rather equally (cf. Halmari \& Virtanen 2005: 5, Dontcheva-Navratilova et al. 2020: 101ff, 341-343). Based on research into different genres within religious discourse (Cotterell \& Turner 1989, Overstreet 2014, Adam 2019, Dontcheva-Navratilova et al. 2020), Table 1 below presents selected prototypical persuasive means that operate within the framework of the three sorts of rhetorical appeal in protestant sermons. 


\begin{tabular}{|l|l|l|}
\hline Ethos & Logos & Pathos \\
\hline $\begin{array}{l}\text { Aim: presentation of values, } \\
\text { strengthening the credibility } \\
\text { and authority of the speaker }\end{array}$ & $\begin{array}{l}\text { Aim: presentation of facts, } \\
\text { enhancing the credibility of the } \\
\text { content }\end{array}$ & $\begin{array}{l}\text { Aim: engaging the listener } \\
\text { through emotions }\end{array}$ \\
\hline $\begin{array}{l}\text { Preacher's personal illustration } \\
\text { (memory, reminiscence, story, } \\
\text { testimony, anecdote) }\end{array}$ & $\begin{array}{l}\text { Biblical quote (repetition of a } \\
\text { verse/passage or quotation of a } \\
\text { new one) }\end{array}$ & $\begin{array}{l}\text { Arousal of emotions, feelings, } \\
\text { creating desired atmosphere }\end{array}$ \\
\hline $\begin{array}{l}\text { Accentuation of the authority } \\
\text { of the church/denomination }\end{array}$ & $\begin{array}{l}\text { Citation of facts from other } \\
\text { sources (statistics, media, } \\
\text { books, poem, song, names, } \\
\text { places, etc.), intertextuality }\end{array}$ & $\begin{array}{l}\text { Turning attention from the text/ } \\
\text { principle/preacher directly to } \\
\text { the audience, listeners }\end{array}$ \\
\hline $\begin{array}{l}\text { Personal moral appeal to the } \\
\text { audience }\end{array}$ & $\begin{array}{l}\text { Logical argumentation and } \\
\text { reasoning (based of causality, } \\
\text { deduction, explication, etc.) }\end{array}$ & $\begin{array}{l}\text { Building a transition to } \\
\text { a principle or doctrine } \\
\text { presentation }\end{array}$ \\
\hline $\begin{array}{l}\text { Recapitulation of a moral } \\
\text { principle }\end{array}$ & Doctrine formulation & $\begin{array}{l}\text { Reminding the audience of } \\
\text { moral connections with their } \\
\text { lives }\end{array}$ \\
\hline
\end{tabular}

Table 1: Typical content of individual persuasive moves

At the same time, it may be argued that, in religious texts, pathos truly represents a flagship of persuasion; it is obviously sentiment in the broadest sense of the word that constitutes the core of the pathetical appeal to the audience (Sancho-Guinda 2019, Adam 2020). The role of pathos is considered to be "instrumental in enhancing the personal involvement of the persuader and creating a rapport with the audience based on communality and shared values, experiences and beliefs" (Dontcheva-Navratilova et al. 2020: 342). It encompasses any sort of affect the persuader employs in the service of persuasion; the persuadee is to be exposed to, influenced and, ideally, convinced by induced emotions. The affective load varies on a scale of emotions, stretching from negative affect, which may be related to the intentional induction of sadness, feeling of guilt and fear to positive sentiment including, for instance, the evocation of reassurance, gratitude and shared joy.

Likewise, the analysis below will look at sermons from this dual perspective; sentiment in the service of persuasion will be explored and interpreted in both the polarities, i.e. positive and negative emotions (Dvořák 2013, Gatti et al. 2014, Petty \& Briñol 2015). It must be noted, at the same time, that the labels 'negative' and 'positive' are rather relative. Fear evoked in the course of a sermon, for instance, is not necessarily to be understood automatically in the negative sense; fear in religious discourse may operate on the level of a positive, desirable affect 
typically related to the feeling of reverence, the sentiment of respect, and awe before God (Overstreet 2014, Adam 2019). By analogy, stirring the audience's positive emotions to evoke sympathy and compassion, no matter how fitting or legitimate these may be, might actually carry traits of manipulation. Research tentatively suggests that affect utilised deliberately by the preacher should be seen as a legitimate means of persuasion as long as it does not trespass over the thin borderline between persuasion and manipulation. Unlike manipulation, i.e. ideology imposed on 'passive victims' whose destiny is to believe or act as they are told, e.g. in medial or political discourse, "in the case of pure persuasion the audience may participate actively in the persuasive process and are free to believe or act as they please, depending on whether or not they accept the arguments of the persuader" (van Dijk 2006: 361, cf. Mulholland 1993).

Before the two-faceted character of the persuasive use of pathos is investigated within the research corpus, I should like to highlight the difference between the notion 'sentiment' on the one hand and 'sentimentality' on the other. Whereas sentiment may be readily seen as a synonym to affect our emotions, sentimentality as a rule involves some degree of exaggeration, naivety and has distinctly coercive potential. In his treatise on beauty in arts, Begbie (2007) discusses three typical features of the 'pathology of sentimentality' in homiletics, maintaining that sentimentality "misrepresents reality by evading or trivializing evil, is emotionally self-indulgent, and fails to take appropriate costly action". He aptly says that when a sermon becomes sentimentalised, the preacher's need to feel good about the experience of preaching might lead to manipulation. It will be interesting to investigate the research corpus in terms of the possible utilisation of such sentimentality with the intent to persuade or even manipulate the audience (ibid.: 53-54).

\section{Linguistic realisations of pathos in sermons}

The analytical part of the paper will monitor and examine various linguistic realisations related to the pathetical appeal used deliberately by preachers to exert persuasion in sermons (the appeals to logos and ethos will be purposefully put aside, though these obviously interact with pathos in an orchestrated interplay). There exists, of course, a whole repertoire of linguistic means of persuasion that are expressed explicitly, typically via the use of persuasive lexicon, be it evaluative adjectives and adverbs, emphatic verbs and nouns, or a sophisticated employment of personal pronouns to construe the preacher's identity and rapport with the audience (Dillard \& Pfau 2002, Halmari \& Virtanen 2005, van Dijk 2006: 374-375, Perloff 2010, Orts Llopis et al. 2017, Dontcheva-Navratilova et al. 2020). The discussion below will, however, pay special attention to those 
realisations that accentuate the persuasive power of sermons in an implicit way, such as deliberate construal of argumentation with the help of pathetical appeal or the thematic build-up of sermons. As a rule, both the positive and negative sentiment will be discussed, one of the key criteria being the fine balance on the edge of sentiment, sentimentality, and, potentially, manipulation.

\subsection{Evoking negative sentiment}

Perhaps the most classic biblical scene that is related to negative emotions employed in sermons is based on the Gospel passages on Jesus' crucifixion. Preachers typically vividly describe the story of Christ's death on the cross, including the accompanying mockery, ridicule, suffering and passion to evoke the atmosphere of utter horror and despair, which usually serves to create a suitable transition to the key Christian doctrine on redemption and salvation. The degree of sentiment stirred varies and so does the actual purpose, which can be rather diverse.

In Example 1, the author first describes the idyllic picture of the birth of Jesus Christ in Bethlehem, taking the listeners almost literally by the hand to introduce them to the narrative. The pastoral, peaceful setting, which is to create a functional prelude to the event that is yet to come, is equipped with corresponding props and characters, such as ewes, lambs, fresh clean hay, manger, and of course Baby Jesus and Mary. The other place, strikingly dissimilar, is Golgotha, the scene of agony, death and crucifixion. Building up a tangible tension, the preacher contrasts the two extraordinarily differing milieux one by one, thus purposefully paving the way for the concluding message to be effective (bold print in the following examples is the author's).

(1) As we cautiously enter this special place, we see the ewes and lambs and the smell of fresh clean hay. During the night the young maiden Mary had given birth to a boy child and wrapped Him in swaddling clothes and because there was no other place (...) Carefully, we make our way to the manger, where the ewes had earlier been fed and peer over to get a look at the mirage of this new born child. He looks like any other baby boy. He is sleeping. His mother is beside the manger watching him in amazement. (...)

Come, let's go up the hill call that was called 'Golgotha'meaning the 'place of the skull' located just outside the walls of Jerusalem and let us look upon this scene. As we grow near we see this is a gruesome place where the Romans brutally crucified their victims. (...) It is a pitiful scene... and emotions whelm up within us as we see His suffering. Then ...we look up at Him, we want to turn away. He is nailed with long spikes to the cross through His hands and feet. He is naked and covered with blood. He has been terribly beaten. He is hardly recognized as a man. We cannot help but look into His marred face, swollen and bloody and we can see the great agony He is suffering. (...) (REL-ENG-9) 
Through the detailed, naturalistic depiction, the audience is made part of the event (this is corroborated at the lexical level by the extensive use of personal inclusive pronouns we/us as well as strongly evaluative adjectives, adverbs, and verbs and nouns marked for emotion). The listeners actually become participants. The tension is strengthened by the frequent use of short sentences with dramatic effect and overwhelming gradation. The emotional juxtaposition of the two immediately successive scenes from Christ's life depicted via a series of sentimental features fosters the persuasive effect of the sermon; nevertheless, the pathetical description has its culmination in the lines which directly follow, in which it becomes even more personalised:

Let us imagine that we are there, standing below His cross. There is a hush and as we look His face... My dear friends, please understand, we are looking into the very face of GOD. (...) The Bible tells us that the agony he is suffering for you and I, and all mankind. Even for those who mocked him and scorned and spit on Him and beat Him. Yes, even for you and I. This pain he is bearing is the penalty of our sin.... Oh, how He must love us! To be God, and to be willing to come to earth and let selfish, sinful man torture him and crucify Him on a cross. (REL-ENG-9)

The message apparently finds its climax in the concluding lines. The point is that the audience was well prepared by being exposed to the emotional experience to be able to understand, grasp and accept the doctrine presented afterwards; being touched and emotional, the persuadees are now more ready and open to absorb what they are offered by the preacher. Even though I am far from judging such persuasive strategies, it seems that such an intentional utilisation of sentiment might teeter on the verge of manipulation and emotional blackmail, albeit in good service and well meant: justified as the sharing of the biblical principle of salvation is, the audience are likely to arrive at the conclusion that they are personally responsible and to blame for Christ's death and so suffer from the aroused feeling of guilt. An appeal to fear is then at play. The idea is that preachers' emotional, often simplifying, self-indulgence may actually prevent 'an atmosphere of free choice' on the part of the audience (Perloff 2010: 12). It is necessary to add that it is not a researcher's job to assess whether and to what degree a manipulative communication takes place; such evaluation, i.e. the opinion whether a speaker's verbal behaviour is acceptable (legitimate) or not, would necessarily lead to subjectivity, if not moralising. The discernment proper will largely be in the persuadees' hands, being bound above all to their own capacity and willingness to accept or reject the teaching offered; manipulation appears to be triggered at the moment of an intentional breach of audience's 
freedom of thought and conscience. In case of manipulation, the persuadees are "unable to understand the real intentions or to see the full consequences of the beliefs or actions advocated by the manipulator", typically lacking "the specific knowledge that might be used to resist manipulation" (van Dijk 2006: 361).

Incidentally, to close one's message by pointing to the cross and reminding the congregation of Christ's redemptive deed seems to be a popular culminating pattern and an underlying persuasive strategy adopted in sermons, no matter what the actual topic is (here, Christmas and Advent, i.e. thematically seemingly the opposite). The story line works for that climax, including corresponding sentiment, such as gratitude and encouragement on the one hand, and frustration, sadness and a feeling of guilt on the other.

Another frequent theme that penetrates the sermons with the intent to persuade through a distinct evocation of sentiment is that of diseases and death. The pattern is very much analogous to the strategy described in Example 1 above; the gloomy narrative serves as a rhetorical springboard for an effective presentation of a biblical principle. Example 3 below illustrates how negative sentiment evoked by the preacher (namely sorrow, compassion and sympathy) leads to a doctrinal postulate that is to be shared with and, ideally, accepted by the audience (God's comfort and reassurance in hardship). Once again, the passage introduces the typical transition from the sentiment triggered by the introductory narrative to the core of the message, supported at the end through a biblical verse and a generalised principle:

Life is like that - we don't know what is coming around the corner, and many things we endure make no sense at all. Sometimes they don't make sense for years to come. And sometimes they never make sense to us. This week I heard about a young woman in her early 20 s who has just been diagnosed with a very serious form of cancer that has spread throughout her body. The cancer is so extensive that surgery is out of the question. For the moment, very difficult chemotherapy is the only possible treatment. No one can say what her long-range prognosis might be. I dare say that for her parents, there is nothing about this that makes sense. In moments like this, rather than try to explain the mysterious ways of God, or try to answer unanswerable questions, we do better to rest on what we know about God - that he is good and just and merciful, that his ways are not our ways, that he makes no mistakes, and he does whatever he pleases (Psalm 115:3). I take great comfort in the fact that our God knows what he is doing, and he uses everything that happens to us to accomplish his purposes in us and through us and for us. (REL-ENG-49)

Employing strong emotions usually goes hand in hand with other linguistic means of interaction and intended persuasion, such as asking rhetorical, i.e. purposefully conducive, questions (Kortum 2013). In them, the preacher seems 
to assume the expected answer, utilising covert persuasive power; the persuadees are confronted with a series of sentiment-provoking and ultimately coercive rhetorical questions. The expected answer is usually obvious and assumed. This rhetorical device is to help the audience to understand the message, inviting them to think, question, examine and evaluate; sometimes, the preachers make use of a whole series of conducive questions in a row to exert pathetical (and ethical) pressure upon the audience, enhancing the interactive and inclusive spirit of sermons and, as a result, help the audience meaningfully apply the doctrine. Example 4 shows how such conducive questions may trigger sentiment:

\begin{abstract}
Philippians 2:10-11 says, "At the name of Jesus every knee should bow, of things in heaven, and things in earth, and things under the earth; And that every tongue should confess that Jesus Christ is Lord, to the glory of God the Father".

How will you respond to Jesus? Will you respond with antagonism, apathy, or adoration? There are people today who will respond in one of these three ways. Some bow up with antagonism (like animals bow up when they feel threatened). Some bow out in apathy (they just don't care enough to get personally involved so they take themselves out of the situation). Some bow down in adoration. Will you bow down to Him today? (REL-ENG-7)
\end{abstract}

In Example 4, the sentiment that is to help to convince the audience is activated via a sophisticated set of questions asked by the preacher. The preacher opens this passage of the sermon by providing a historical-cultural context of the event under discussion and shares a related biblical verse. This move is followed by a number of thought-provoking rhetorical questions that are directly targeted at the congregation. The persuadees (the congregation) are actually given a 'controlled choice', with the preacher leading their mental exercise and suggesting an implied answer (Dvořák 2012, 2013, Adam 2019). The audience is personally challenged to take a stance through the pathetical appeal, the sentiment of which consists of appealing to their expected gratefulness to Jesus and feeling of obligation. The sentiment induced in the listeners' minds thus includes the emotions of remorse, implied reproach, anxiety, frustration, negative assumptions, and the like. The context of this persuasive attempt is heavily determined by the emotions aroused deliberately by the preacher: one must choose the right side. The closing suggestive question adds the necessary portion of pathos in play, directly placing the audience into a position in which they are expected to respond. Such prefabricated answers operate, as a rule, in the framework of a black-and-white prism which is adopted throughout the preacher's argumentation. Based on the doctrine, things are presented as either good or bad, creating ideological conflict; one's implied response is either yes or 
no (cf. van Dijk 2006: 373). The goal of such a persuasive attempt is an active realisation of the desired conviction, and, finally, a practical act on the part of the addressee. The ultimate aim of this persuasive strategy is to persuade the audience of their imperfections, their spiritual needs and a pertinent response.

Example 5 below introduces perhaps the most overt and direct way of the employment of negative sentiment in sermons, namely the appeal to fear.

\begin{abstract}
We have a choice as to which of the last scenes in history will we stand by. God has provided that if we believe in Jesus Christ, in faith repenting of our sins, we are assured that we will be in the Rapture, caught up to meet the Lord in the air when He comes for the children of God. Or we can choose not to accept His offer of forgiveness of sin and eternal life and because men are sinners, they stand condemned already to the Devil's hell.

If there is one here today who has not placed his or her trust in Christ Jesus, this day can be a time of joy and rejoicing for you also. The Bible says that all who have not received Jesus Christ as their Savior stand condemned by their sin. Yet, Christ came to the world, suffered and died for you, that you might have eternal life. You can today, in repentance ask God even at this moment to save you. (REL-ENG-9)
\end{abstract}

The fear-related emotions induced in this sermon passage encompass an open threat and fear of condemnation. The choice that the congregation is facing is presented in a clear and indicative way. On top of it, the final suggestive appeal is voiced as rather personal (You can ...). The message between the lines clearly communicates the need to act immediately and, so to speak, to take the chance here and now. A fear appeal, as a term used in psycholinguistics (Dillard \& Peck 2001, Dillard \& Anderson 2004, Tannenbaum et al. 2015), is understood as a persuasive attempt that is meant to arouse fear in order to alter or divert one's behaviour through the threat of impending danger or harm with the aim to create support for an idea and to persuade. It follows that through a fear appeal the target individual or group of individuals experiences an unpleasant cognitive, emotional and behavioural response, i.e. fear arousal (van Dijk 2006, Tannenbaum et al. 2015).

Appeal to fear is typical of the discourse of politics, marketing and medicine; in them, fear appeal strategies are adopted to change attitudes, to avoid and to eliminate the persuadees' fallacies and decrease their self-efficacy. Religious discourse, however, seems to use traits of fear appeal if persuasive attempts balance on the verge of emotional abuse and toy with manipulation, typically in religious cults (cf. Dvořák 2012). This is usually achieved through intentional use of exaggeration, emotionally charged vocabulary and vivid imagery, which in effect co-create a coercive pressure on the audience, leaving them no space for 
critical thinking. Of course, whether one is dealing with manipulation or not very much depends on the degree to which the preacher uses/abuses the persuasive means, on the context of the situation as well as on the mental maturity of the persuadees (cf. van Dijk 1998, 2006). On the whole, fear appeal definitely falls into the category of the most coercive, and debatable, persuasive strategies observed in sermons.

\subsection{Evoking positive sentiment}

As has been observed above, positive sentiment within the corpus of sermons on Christmas and Advent is usually related to the very centrepiece of the Scripture, namely to the birth of Jesus Christ in the town of Bethlehem. Even though it is only rarely that this event is presented as a straightforward, naïve idyll that would stir the audience's positive emotions, it is often used as an opening account for messages of many sorts, including those with persuasive power.

The first extract below (Example 6) offers a New Testament character whose role in the Christmas story is not primary, yet is significant: Elizabeth, the mother of John the Baptist and a close relative to Mary. Though past the years of childbearing, Elizabeth is promised a child by the Angel of the Lord. The sermon passage below illustrates how the sweet sentiment evoked by the preacher gradually proceeds to the final presentation of a biblical postulate:

(6) Elizabeth was sensitive, aware of the Holy Ghost working in her! You see this was deep calling unto deep! This was the deep of the Holy Ghost speaking through Mary to Elizabeth. Oh, the blessing of that lovely sensitivity to the Holy Spirit speaking to us and through us! (...) Her heart beats fast with hope and anticipation! Listen to what she had been told by the angel. Luke 1:14-17, "And thou shalt have joy and gladness; and many shall rejoice at his birth. (...)”"

Elizabeth, in the quietness of her priestly home and city must have been deeply aware of the power of God working in her producing something for which she had long prayed but by now must surely have given up hope. After all she was past the years of childbearing, her prayer had been made in younger days, in days of expectancy.

Oh, beloved, never lose sight of what God can do with you and through you! (REL-ENG-4)

The lines cited convey the sheer joy and peaceful excitement Elizabeth is experiencing. Not only are the emotions accentuated lexically (deep calling, blessing of that lovely sensitivity, Her heart beats fast with hope and anticipation, joy and gladness, etc.), but also at the syntactical level. Note, for instance, the reiterative use of exclamation marks (four times in the extract under scrutiny) and the number of exclamations as such. Unlike some other persuasive 
discourses, exclamations in sermons actually constitute a major category in terms of speech act analysis. It is evident that exclamations are employed primarily for the purposes of emphatic use, the marginal functions being those of a summarizer, and attention-getter (Dontcheva-Navratilova et al. 2020). The role of exclamations is inevitably related to the conveyance of the emotive load, which leads to a pathetical appeal to the audience and rhetoric persuasive pressure imposed on the hearer. Sentiment enables the preacher to generalise the principle: with the ground prepared, he may take another step and formulate the core of his message: Oh, beloved, never lose sight of what God can do with you and through you! Thus, owing to the emotions originally created around a biblical character, the narrative presented is made very personal and up-to-date (which is further enhanced by the emphatic use of initial interjection and the form of address $($ Oh, beloved $)$ ).

Example 7 features, for a change, a contemporary living person who is given as a model for the congregation. After a relatively long narrative introduction, the audience is overwhelmed with a climax abundant in positive sentiment:

\begin{abstract}
The story is told of a little boy who was chosen to play the innkeeper in the annual children's Christmas play at his church. When the night came, all the children were in their places, nervously waiting for the play to begin. The girls were dressed as angels, the boys as shepherds and Wise Men. While the little girls talked and giggled, the boys poked each other with their shepherds'staffs. The little boy chosen to play the innkeeper had only one line. When Joseph knocked on the door, he was to open it and tell them there was no room in the inn.

As the play began, parents and grandparents wondered how their children would do that night. Everything proceeded as planned. At last, the big moment came for the innkeeper. Joseph knocked on the door. The young boy opened it and saw Joseph and the very pregnant young girl. Something about the sight of Mary touched his heart, and he blurted out the show-stopping lines, "There is no room left in the inn... but you can share my room!" Some people thought the Christmas pageant had been ruined. Others thought it was best one ever. The little boy told the frustrated director later: “I just couldn't send Jesus away. I had to find a place for Jesus."
\end{abstract}

There was no room for Jesus that night in Bethlehem. Will you make room for him in your heart this year? (REL-ENG-49)

The preacher's account begins with a lovely depiction of the atmosphere before the children's Christmas play. The kids cannot wait to say their lines, shivering with nervousness. This light-hearted prelude is replaced with a moving description of the audience's awakened expectations. In this way, gradual tension is built before our eyes. And then, rather suddenly, comes the unexpected climax: the sincere words uttered by the boy actor provide the story with a pathetical 
conclusion, which is eventually targeted at every individual in the audience. The powerful effect of the emotional load is enhanced by the inclusion of direct speech citations. The moral is finally accentuated by the preacher's finale in the form of an explicit summary and an urging rhetorical question; sentiment is apparently in action both in the anticipatory phase and the core message.

The last text sample (Example 8) shows how the preacher utilises intertextuality to evoke emotions:

\begin{abstract}
Jesus saw everyone he came into contact with as a person of dignity. Once people encountered Jesus, they were never the same again. They were transformed in every way. (...) This is God's dream and it is the hope of Christmas. There's a children's book by Dr Seuss called "How the Grinch Stole Christmas". In the book, the Grinch hated Christmas and stole all the gifts and decorations and food that the people of Whoville had prepared for Christmas. But as the people overcame the loss and continued to sing \& celebrate the Grinch underwent a transformation and discovered that there's more to Christmas than the trappings. He saw how love and sharing and being together in community brings happiness, not the presents and the trappings. His heart grew three sizes! The Grinch saw and then experienced Christmas as the light of Christ shining brightly in the darkness, and burning into his heart, and spreading into the hearts of others.

May Christmas touch you in a new way this year, as you respond to the news of Christ's birth. And may your search lead you to find Christ's presence in your life warming your heart, filling you with peace, love, joy and hope and lighting your way. AMEN. (REL-ENG-35)
\end{abstract}

Opening with a statement on the changing power of meeting Jesus, he goes on to tell a story of a children's book; through it, he creates a sentimental mood (people's moral reaction to the Grinch's theft, the spirit of admiration), which in turn serves as a springboard for the final conclusive ethical message to the audience, consisting of a set of suggestive wish-clauses that appeal to the persuadees' gratitude and a meaningful Christmas. Again, sentiment underlies the preacher's argumentation in all its stages.

\title{
7 Conclusions
}

The paper has shown that sentiment, being a powerful persuasive means in the service of pathos, appears to be systematically and intricately interwoven in sermons. The pathetical appeal is triggered by an evocation of emotions of various sorts through different motifs and themes, here inevitably associated with Advent and Christmas. Table 2 summarises the most frequent pathos-related themes of the sermons under scrutiny (some of which are not subject to the present analysis) along with the desired emotional response of the audience: 


\begin{tabular}{|l|l|}
\hline Negative Pathetical Themes & Positive Pathetical Themes \\
\hline Jesus' crucifixion on Golgotha & Jesus' birth in Bethlehem \\
\hline Disease, suffering, death & $\begin{array}{l}\text { Touching stories of exemplary individuals } \\
\text { (godly, good-hearted, faithful, perseverant) }\end{array}$ \\
\hline $\begin{array}{l}\text { Existential troubles (lack of money, } \\
\text { homelessness) }\end{array}$ & $\begin{array}{l}\text { Positive values (fellowship, good relationships, } \\
\text { unity) }\end{array}$ \\
\hline $\begin{array}{l}\text { Spiritual consequences - condemnation, hell, } \\
\text { separation from God }\end{array}$ & $\begin{array}{l}\text { Spiritual consequences - eternal life, being in } \\
\text { God's presence }\end{array}$ \\
\hline $\begin{array}{l}\text { Unrequited 'Christmas present', i.e. wasted } \\
\text { sacrifice }\end{array}$ & $\begin{array}{l}\text { Meaningful Christmas, requited 'Christmas } \\
\text { present' }\end{array}$ \\
\hline $\begin{array}{l}\rightarrow \text { Pathos-related emotional effect: } \\
\text { Fear, sadness, frustration, feeling of guilt, } \\
\text { feeling of inadequacy, humiliation, shame, } \\
\text { disappointment }\end{array}$ & $\begin{array}{l}\rightarrow \text { Pathos-related emotional effect: } \\
\text { Joy, peace, reassurance, encouragement, } \\
\text { tranquillity, reconciliation, warmth, gratitude }\end{array}$ \\
\hline
\end{tabular}

Table 2: Typical themes related to pathos in sermons on Christmas and Advent

Interestingly enough, emotions deliberately evoked by the preacher operate as a double-edged tool of persuasion: both the negative and positive emotive load is capable of enhancing the persuasive effect, whether it resides in preparing the ground for the climax of the sermon (the bridging or contrasting function) or as an intrinsic vehicle of the message. In consequence, the message conveyed is more personal, more appealing and more readily accessible - and thus persuasive - to the audience. All in all, in the sermons under scrutiny, this Janus-faced nature of sentiment seems to constitute the quintessence of the persuasive power.

Furthermore, it has become obvious that both the polarities of sentiment actually teeter on the brink of sentimentality or even manipulation. But what is the borderline? The thing is, manipulation is a complex phenomenon that is not easily defined; nevertheless, research into persuasion in sermons indicates that it is determined not only by discursive, but also cognitive and social aspects of human communication in the broadest sense, and that its assessment by an outsider is by definition prone to subjectivity. The analysis suggests that pathetical appeal leads to sentimentality if the preachers in their persuasive attempts resort to exaggeration, naivety, superfluous simplification, misrepresentation of reality and inclination to emotional self-indulgence. Such exercise of power would result in manipulative preaching.

I argue, however, that a mere text of a sermon cannot exert manipulation on its own; obviously, there must be a manipulative intention and effort on the part of the preacher, who can twist the homiletic content into a coercive imposition and manoeuvre the audience to the prefabricated conclusions at any cost. Nevertheless, to identify such an intent to manipulate remains a delicate 
and somewhat speculative issue. As van Dijk (2006) maintains, "manipulation is not (only) 'wrong' because it violates conversational maxims or other norms and rules of conversation" (ibid.: 363). In other words, on the one hand, the decisive criterion in the discussion on the thin and blurred borderline between sentiment and manipulation in sermons appears to be directly connected with the character and rhetoric skills of the preacher, and, on the other hand, with the liberal environment of the church, i.e. the free will and common sense of the congregation. Given these circumstances, the pathetical appeal may do its legitimate job, helping the audience to comprehend the message effectively, but not to be passive victims who have no space to think critically and disagree. The analysis indicates that it is especially the methods of emotional blackmail and fear appeal that may slide towards manipulation. The preacher then exercises controlled persuasion, i.e. deliberate manipulation, in the course of which the end justifies the means.

Let me conclude in line with van Dijk (2006) by saying that genuine persuasion pursued in sermons should enable the audience to take an active part in the persuasive process so that the interlocutors would be "free to believe or act as they please, depending on whether or not they accept the arguments of the persuader" (ibid.: 361). Sentiment in the service of pathetical appeal will then operate as any other legitimate tool of pure persuasion with the ethical standards and the preacher's moral integrity maintained.

\section{References}

Adam, M. (2017) 'Persuasion in religious discourse: Enhancing credibility in sermon titles and openings.' Discourse and Interaction 10(2), 5-25.

Adam, M. (2019) 'Enhancing persuasion in sermon conclusions through fear induction.' In: Crhová, M. and Weiss, M. (eds) Silesian Studies in English 2018. Proceedings of the $5^{\text {th }}$ International Conference of English and American studies. Opava: Silesian University in Opava. 7-23.

Adam M. (2020) 'Persuasion in religious discourse: Employing humour to enhance persuasive effect in sermons.' In: Dontcheva-Navratilova, O., Adam, M., Povolná, R. and Vogel, R. Persuasion in Specialised Discourses. Postdisciplinary Studies in Discourse. Cham: Palgrave Macmillan. 197-227.

Begbie, J. S. (2007) 'Beauty, sentimentality and the arts.' In: Treier, D., Husbands, M. and Lundin, R. (eds) The Beauty of God: Theology and the Arts. Downers Grove, IL: InterVarsity Press. 45-69.

Bhatia, V. (1993) Analysing Genre: Language Use in Professional Settings. London: Longman.

Connor, U. (2004) 'Intercultural rhetoric research: Beyond texts.' Journal of English for Academic Purposes 3(4), 291-304.

Cotterell, P. and Turner, M. (1989) Linguistics and Biblical Interpretation. Downers Grove, IL: InterVarsity Press. 
Dillard, J. P. and Peck, E. (2001) 'Persuasion and the structure of affect: Dual systems and discrete emotions as complementary models.' Human Communication Research 27(1), 38-68.

Dillard, J. P. and Pfau, M. (eds) (2002) The Persuasion Handbook: Developments in Theory and Practice. Thousand Oaks, CA: Sage.

Dillard, J. P. and Anderson, J. W. (2004) 'The role of fear in persuasion.' Psychology and Marketing 21(11), 909-926.

Dillard, J. P. and Seo, K. (2013) 'Affect and persuasion.' In: Dillard, J. P. and Shen, L. (eds) The Sage Book of Persuasion: Developments in Theory and Practice. London: Sage. 150-166.

Dontcheva-Navratilova, O., Adam, M., Povolná, R. and Vogel, R. (2020) 'Persuasive strategies across the academic, business, religious and technical discourses.' In: Dontcheva-Navratilova, O., Adam, M., Povolná, R. and Vogel, R. Persuasion in Specialised Discourses. Postdisciplinary Studies in Discourse. Cham: Palgrave Macmillan.

Duffy, M. and Thorson, E. (2016) Persuasion Ethics Today. London and New York: Routledge.

Dvořák, M. (2012) 'Fear induction, versatile wide-coverage taints, semantic polarity and semantic association as means of persuasion in religious discourse.' In: International Symposium on Language and Communication: Research Trends and Challenges: Proceedings Book. Izmir: Institute of Language and Communication Studies. 497-509.

Dvořák, M. (2013) 'Means of increasing credibility in religious discourse.' Language and Communication Quarterly 2(4), 230-241.

Fairclough, N. (1989) Language and Power. London: Longman.

Garzone, G. E. (2017) 'Persuasive strategies on surrogacy websites: A discourse-analytical and rhetorical study.' In: Orts Llopis, M. Á., Breeze, R. and Gotti, M. (eds) Power, Persuasion and Manipulation in Specialised Genres. Providing Keys to the Rhetoric of Professional Communities. Bern: Peter Lang. 101-130.

Gatti L., Guerini, M., Stock, O. and Strapparava, C. (2014) 'Sentiment variations in text for persuasion technology.' In: Spagnolli, A., Chittaro, L. and Gamberini, L. (eds) Persuasive Technology, Vol. 8462. Cham: Springer.

Halmari, H. and Virtanen, T. (eds) (2005) Persuasion across Genres. Amsterdam and Philadelphia: John Benjamins.

Hogan, M. (2013) 'Persuasion in the rhetorical tradition.' In: Dillard, J. P. and Shen, L. (eds) The Sage Book of Persuasion: Developments in Theory and Practice. London: Sage Publications. 2-19.

Holtgraves, T. M. (2001) Language as Social Action: Social Psychology and Language Use. Mahwah, New Jersey: Lawrence Erlbaum Associates Publishers.

Hunston, S. (2007) 'Using corpus to investigate stance quantitatively and qualitatively.' In: Englebretson, R. (ed.) Stancetaking in Discourse. Amsterdam and Philadelphia: John Benjamins. 27-48.

Kortum, R. D. (2013) Varieties of Tone. London: Palgrave Macmillan.

Lempert, M. (2015) 'Discourse and religion.' In: Tannen, D., Hamilton, H. E. and Schiffrin, D. (eds) The Handbook of Discourse Analysis, 2. Maldon, Oxford: Blackwell Publishers. 902-919.

Mulholland, J. (1993) A Handbook of Persuasive Tactics: A Practical Language Guide. London and New York: Routledge.

Onions, C. T. (ed.) (1996) The Oxford Dictionary of English Etymology. Oxford: Oxford University Press. 
Orts Llopis, M. Á., Breeze, R. and Gotti, M. (eds) (2017) Power, Persuasion and Manipulation in Specialised Genres. Providing Keys to the Rhetoric of Professional Communities. Bern: Peter Lang.

Overstreet, L. R. (2014) Persuasive Preaching: A Biblical and Practical Guide to the Effective Use of Persuasion. Wooster: Weaver Book Company.

Perloff, R. (2010) The Dynamics of Persuasion. Communication and Attitudes in the $21^{\text {st }}$ Century. $4^{\text {th }}$ ed. New York and London: Routledge.

Petty, R. E. and Briñol, P. (2015) 'Emotion and persuasion: Cognitive and meta-cognitive processes impact attitudes.' Cognition and Emotion 29(1), 1-26.

Sperber, D., Clément, F., Heintz, C., Mascaro, O., Mercier, H., Origgi, G. and Wilson, D. (2010) 'Epistemic vigilance.' Mind and Language 25, 359-393.

Sancho-Guinda, C. (ed.) (2019) Engagement in Professional Genres. Amsterdam and Philadelphia: John Benjamins.

Swales, J. (1990) Genre Analysis: English in Academic and Research Settings. Cambridge: Cambridge University Press.

Tannenbaum, M. B., Hepler, J., Zimmerman, R. S., Saul, L., Jacobs, S., Wilson, K. and Albarracín, D. (2015) 'Appealing to fear: A meta-analysis of fear appeal effectiveness and theories.' Psychological Bulletin 141(6), 1178-1204.

van Dijk, T. A. (1998) Ideology: A Multidisciplinary Approach. London: Sage.

van Dijk, T. A. (2006) 'Discourse and manipulation.' Discourse \& Society 17(2), 359-383.

van Dijk, T. A. (2008) Discourse and Power. Basingstoke, UK and New York: Palgrave Macmillan.

van Leeuwen, T. (1996) 'The representation of social actors.' In: Caldas-Coulthard, C. R. and Coulthard, M. (eds) Texts and Practices: Readings in Critical Discourse Analysis. London: Routledge. 32-70.

Virtanen, T. and Halmari, H. (2005) 'Persuasion across genres: Emerging perspectives.' In: Halmari, H. and Virtanen, T. (eds) Persuasion across Genres. Amsterdam and Philadelphia: John Benjamins. 3-24.

Martin Adam is Associate Professor at the Department of English Language and Literature, Masaryk University, Brno. In his research, he specialises in the theory of functional sentence perspective (FSP) and religious discourse. Apart from a number of journal articles and book chapters, he is the author of $A$ Handbook of Functional Sentence Perspective (2008) and two monographs: Functional Macrofield Perspective (2009) and Presentation Sentences (Syntax, Semantics and FSP) (2013). Recently Martin Adam co-authored Persuasion in Specialised Discourses published with Palgrave Macmillan in 2020.

Address: doc. Mgr. Martin Adam, Ph.D., Department of English Language and Literature, Masaryk University, Poříčí 9, Brno 603 00, Czech Republic. [e-mail: adam@ped.muni.cz] 